\section{Rootstock Affects Yield, Yield Efficiency, and Harvest Rate of 'Kensington Pride' Mango}

\author{
Malcolm W. Smith ${ }^{1}$, Mark D. Hoult ${ }^{2}$, and Jeremy D. Bright ${ }^{3}$ \\ Katherine Research Station, Northern Territory Department of PrimaryIndustry \\ and Fisheries, Katherine 0851, Australia
}

Additional index words. yield variability, Mangifera indica, harvest costs, tree size, canopy silhouette area

\begin{abstract}
Low yields and high harvesting costs are long-standing problems in mango (Mangifera indica L.) cultivation. In an effort to increase productivity in the scion 'Kensington Pride' we examined the impact of nine different rootstocks over a 10-year period. Rootstock effects on fruit production were significant in most seasons, and cumulative yields (nine seasons of cropping) for the best treatment ('Sg. Siput') exceeded those of the poorest treatment ('Sabre') by $141 \%$. Yield efficiencies (expressed on both a trunk cross-sectional area and canopy silhouette area basis) were also significantly affected by rootstock. Rootstock effects on yield and yield efficiency were generally consistent across seasons, despite large seasonal variations in yield. Harvest rates were also influenced by rootstock, and were poorly correlated with tree size. These results demonstrate possibilities for manipulating mango scion productivity through rootstock genotype.
\end{abstract}

Despite cultivation in a wide range of environments, all commercial mango producers face major problems with high costs of production, comparatively low yields (Galán Saúco, 1997a), and irregular bearing (Schaffer et al., 1994). Wolstenholme and Whiley (1995) suggest "good grower target yields" of 5-10 $\mathrm{t} \cdot \mathrm{ha}^{-1}$ in the lowland tropics and $15-20 \mathrm{t} \cdot \mathrm{ha}^{-1}$ in the hot subtropics, although few mango producing countries report national average yields in excess of $10 \mathrm{t} \cdot \mathrm{ha}^{-1}$ (FAO 2001).

Genetic improvement, through scion and rootstock breeding and selection, is seen as offering some of the best prospects for improvement in mango cultivation (Chapman, 2000; Galán Saúco, 1997a). However, while scion breeding programs may improve productivity (Lavi et al., 1997; Negi, 2000; Whiley and Saranah, 1995) they carry with them significant commercial difficulties associated with market familiarity and consumer acceptance. Production in many countries is dominated by a small number of cultivars, and there has been limited change in the relative importance of these cultivars in the last few decades (Galán Saúco, 1997b). For example, one cultivar 'Kensington Pride', accounts for $\approx 90 \%$ of mango production in Australia and is in high demand by consumers and processors (Crane et al., 1997).

Rootstock improvement is of major significance in many tree crops, yet it is an area

Received for publication 31 Dec. 2001. Accepted for publication 19 June 2002.

${ }^{1}$ Current address: Queensland Dept. of Primary Industries, 49 Ashfield Rd., Bundaberg 4670, Australia.

${ }^{2}$ Current address: Berrimah Agricultural Research Centre, Northern Territory Dept. of Primary Industry and Fisheries, Darwin 0801, Australia.

${ }^{3}$ Current address: NSW Agriculture, Forest Road, Orange 2800, Australia.

E-mail: jeremy.bright@agric.nsw.gov.au that has received limited exploration in mango. The general absence of major root disease or nematode problems in mango cultivation may partly explain this situation (Cull, 1991). Ram (1997) reviewed the existing literature on rootstocks for mango, and highlighted the need for more research on the subject. Recently, additional benefits in terms of fruit quality (Avilán et al., 1997; Smith et al., 1997) and resistance to a soil-borne pathogen (Rossetto et al., 1997) have been reported.

Improved scion and rootstock cultivars both offer the prospect of increasing mango yield and productivity without increasing production costs. However, within a commercial environment where there is strong consumer preference for an existing scion cultivar, improved rootstocks may offer a means of addressing production issues without creating marketing difficulties associated with a new scion cultivar. In this study, we examined the performance of nine different rootstock genotypes over a 10 -year period to determine whether they affected the yield and/or yield efficiency of 'Kensington Pride'. Effects on fruit harvest rates were also examined.

\section{Materials and Methods}

Seeds from nine different polyembryonic accessions (Table 1) were collected from the Northern Territory mango germplasm repository (Scholefield et al., 1986) and sown individually in 5-L pots. After 6 months growth, the seedlings were grafted with 'Kensington Pride' scion wood at a height of $\approx 200 \mathrm{~mm}$. In Jan. 1985, 8 months after grafting, trees were field planted within a commercial mango orchard near Katherine, Northern Territory, Australia (lat. $14^{\circ} 28^{\prime} \mathrm{S}$, long. $132^{\circ} 18^{\prime} \mathrm{E}$ ). This region experiences a semi-arid tropical environment with an intense wet season (average $972 \mathrm{~mm}$ per year) from December to February followed by a distinct dry period for most of the remaining months. Orchard management followed standard commercial practices, as described in Crane et al. (1997). Pruning was restricted to establishing a strong framework of branches, preventing fruit developing on the ground (skirting), and enabling spray penetration of the canopy (light internal branch thinning). The soil type was a Venn sandy loam (sandy, Typic Alfisol). Ground-water, used for irrigation, contains calcium bicarbonate which causes an increase in soil $\mathrm{pH}$ to between 8 to 8.5 , while electrical conductivity remains low $\left(<0.05 \mathrm{dS} \cdot \mathrm{m}^{-1}\right)$.

Trees were arranged in a randomized complete-block design with six single tree replications of each of the nine rootstock treatments. Trees were spaced at $5 \mathrm{~m}$ within the row and $13.5 \mathrm{~m}$ between rows. Whole tree yields were measured for 1987 through 1996, (excluding 1991). Harvest date was determined by testing internal fruit maturity and normally occurred in early November of each season. The complete absence of rain for at least 3 months prior to flowering, coinciding with the onset of cooler night temperatures, produced synchronous flowering in each year of the experiment. This in turn resulted in uniform fruit maturity and enabled all fruit to be removed in a single harvest (which is the standard commercial practice in most seasons in this production region). Fruit number, weight, and tree harvest time (harvest rate) were recorded for each tree in the experiment.

Tree size was determined using two methods and these measurements were then used to calculate yield efficiencies. One of these methods expressed tree size in terms of the area of the projected canopy silhouette of each tree ["canopy silhouette area" (CSA)], while the other method expressed tree size in terms of the dimensions of the trunk ["trunk cross-sectional area" (TCA)]. CSA was measured in 1991, 1993, and 1996 using methods similar to those described in Richards (1992). Photographs were taken from each side of each tree and scanned into image processing software (SigmaScan; SPSS, Chicago). The tree outline on each image was traced and the number of pixels within the traced area computed. A marker board (of known area) held at the edge of the tree canopy on each image was then traced and used to scale each measurement.

Trunk circumference was measured slightly below the graft union, $\approx 200 \mathrm{~mm}$ above ground level. These measurements were made each season from 1990 to 1996 (excluding 1991 and 1993), and used to calculate TCA. Data analysis was performed using analysis of variance and correlation procedures within GENSTAT (Genstat 5; Lawes Agricultural Trust, Rothamsted, England).

\section{Results}

Rootstock had a marked impact on fruit yield commencing when trees were young (4 years) and continuing throughout the experimental period (Table 1). On an individual season's basis, differences between rootstocks 
were significant in all seasons, with the exceptions of 1987 and 1989 (the two lowest-yielding seasons). By the end of the experiment the cumulative yield (nine seasons of cropping) of the most productive treatment ('Sg. Siput') was $919 \mathrm{~kg} /$ tree compared with $382 \mathrm{~kg} /$ tree for the lowest yielding treatment ('Sabre'). Indeed the cumulative yield of 'Sg. Siput' was $41 \%$ higher than the next highest yielding rootstock ('False Julie') at $652 \mathrm{~kg} /$ tree.

Yield efficiency was also affected by rootstock treatment. Expressed on a CSA basis, yield efficiency differences were significant in all three seasons when measurements were made (Table 2). Differences in yield efficiency between rootstocks were large, with some treatments carrying in excess of three times as much fruit per square metre of CSA as other treatments. 'Sg. Siput' consistently recorded the highest yield efficiency values (when expressed on a CSA basis). Conversely treatments such as 'Sabre' generally performed poorly, while others like 'Lemon D2' had comparatively high yield efficiencies in some seasons but very low efficiencies in other seasons.

When yield efficiency was expressed on the basis of TCA, rootstock differences were significant in three out of the five seasons measured (Table 3). Trends were similar to those shown in CSA data, except that 'Sg. Siput' did not record the highest yield efficiency values in all seasons.

Harvest rate was influenced by rootstock treatment in 1993 and 1995, but not in 1994 (Table 4). In 1993, 37\% more fruit was picked per minute from the best treatment ('False Julie') than from the worst ('Sabre'), while in 1995 the harvest rate of 'Sg. Siput' (2.13 $\mathrm{kg} /$ person/min) was more than twice that of 'Teluk Anson' (0.99 kg/person/min).

These differences in harvest rates for different rootstock treatments were examined in the context of tree size measurements (Table 5). Correlations were performed between the three harvest rate figures (1993, 1994, and 1995), and measurements of CSA(1990, 1993, and 1996), and TCA (1990, 1992, 1994, 1995, and 1996).

The correlations between these 11 variables was examined on an individual tree basis ( $\mathrm{N}$ =54). Correlations between CSA and harvest rates ranged from -0.144 to 0.517 . Similarly, correlations between TCA and harvest rates ranged from -0.075 to 0.335 .

An attempt was also made to explain harvest rate differences in terms of yield efficiency (Table 6). To do this, correlations were examined between the three harvest rate figures (1993, 1994, and 1995), yield efficiency based on CSA (1990, 1993 and 1996) and yield efficiency based on TCA (1990, 1992, 1994, 1995, and 1996). Correlations between yield efficiency (CSA basis) and harvest rates ranged from -0.030 to 0.493 . Yield efficiency (TCA basis) and harvest rate correlations ranged from -0.082 to 0.764 .

\section{Discussion}

Yield, yield efficiency and harvest rate of 'Kensington Pride' mango are influenced by rootstock. These effects were evident when trees were young, and continued throughout most of the 10-year assessment period. Such findings are in agreement with significant yield effects that have been reported for a number of other scion cultivars in different countries (Avila-Reséndiz et al., 1993; Gowder and Irulappan 1971; Kurian et al., 1996; Oppenheimer, 1968; Samaddar and Chakrabarti, 1988) although they are of greater magnitude and/or seasonal consistency than any previously reported work. Impacts on yield efficiency also support the existing literature (Avila-Reséndiz et al., 1993; Kurian et al., 1996; Samaddar and Chakrabarti, 1988) in demonstrating good prospects for increasing mango yield efficiency through improved rootstocks. Other reports of rootstock effects on harvest rates are apparently lacking.

'Kensington Pride' like most mango cultivars is a fast growing terminal bearing tree capable of achieving considerable size, particularly in the tropics (Crane et al., 1997). Consequently, yields expressed on a per tree basis are determined to a significant extent by tree size. Yield efficiency measurements that take account of tree size provide for more meaningful interpretation both between rootstock treatments and across different seasons and experiments. These measurements may also aid in the important task of defining optimum plant densities for each rootstock/scion combination (Galán Saúco, 1997a). Perez et al. (1988) measured mango yield efficiency in terms of canopy volume, and found that efficiency decreased as trees grew older and larger. This is not surprising for a terminal bearing species where the surface area to volume ratio decreases as tree size increases. For this reason, the methods of expressing yield efficiency used in our work (TCA and

Table 1. Annual and cumulative fruit yield of 'Kensington Pride' mango trees on nine rootstocks in the first 10 years of cropping (excepting 1991).

\begin{tabular}{llllllllllc}
\hline & \multicolumn{10}{c}{ Yield (kg/tree) } \\
\cline { 2 - 11 } Rootstock & 1987 & 1988 & 1989 & 1990 & 1992 & 1993 & 1994 & 1995 & 1996 & Cumulative \\
\hline Sg. Siput & 4 & 51 & 7 & 88 & 125 & 199 & 217 & 108 & 121 & 919 \\
False Julie & 0 & 17 & 4 & 30 & 105 & 138 & 221 & 51 & 87 & 652 \\
Pineapple & 0 & 23 & 9 & 46 & 87 & 118 & 197 & 51 & 57 & 588 \\
Kensington Pride & 1 & 25 & 9 & 45 & 85 & 103 & 150 & 45 & 50 & 513 \\
Teluk Anson & 2 & 24 & 15 & 43 & 96 & 101 & 152 & 32 & 34 & 499 \\
Strawberry & 1 & 8 & 12 & 21 & 80 & 92 & 143 & 39 & 73 & 468 \\
Mempelam Telur & 4 & 18 & 15 & 28 & 72 & 83 & 139 & 44 & 66 & 468 \\
Lemon D2 & 0 & 6 & 3 & 18 & 59 & 103 & 140 & 32 & 62 & 422 \\
Sabre & 5 & 13 & 15 & 34 & 71 & 62 & 115 & 43 & 24 & 382 \\
$P$ value & 0.089 & $<0.001$ & 0.343 & $<0.001$ & 0.013 & $<0.001$ & 0.004 & 0.005 & $<0.001$ & $<0.001$ \\
LSD & $\mathrm{NS}$ & 14.8 & $\mathrm{NS}$ & 27.2 & 33.1 & 48.0 & 58.0 & 36.3 & 39.2 & 181 \\
\hline
\end{tabular}

Table 2. Yield efficiency, based on canopy silhouette area (CSA), of 'Kensington Pride' mango trees on nine rootstocks.

\begin{tabular}{lccl}
\hline & \multicolumn{3}{c}{ Yield efficiency } \\
\cline { 2 - 4 }$\left(\mathrm{kg} \cdot \mathrm{m}^{-2} \mathrm{CSA}\right)$ \\
\hline Rootstock & 1990 & 1993 & 1996 \\
\hline Sg. Siput & 10.6 & 12.9 & 4.2 \\
False Julie & 4.0 & 8.9 & 3.5 \\
Pineapple & 7.0 & 10.5 & 3.1 \\
Kensington Pride & 7.5 & 8.8 & 2.7 \\
Teluk Anson & 6.8 & 8.6 & 2.0 \\
Strawberry & 4.2 & 7.7 & 3.6 \\
Mempelam Telur & 4.5 & 7.1 & 3.5 \\
Lemon D2 & 2.9 & 9.1 & 3.0 \\
Sabre & 5.7 & 5.1 & 1.2 \\
$P$-value & 0.004 & $<0.001$ & 0.002 \\
LSD $_{0.05}$ & 3.59 & 2.62 & 1.35 \\
\hline
\end{tabular}

Table 3. Yield efficiency, based on trunk cross-sectional area (TCA), of 'Kensington Pride' mango trees on nine different rootstocks.

\begin{tabular}{lccccc}
\hline & \multicolumn{5}{c}{ Yield efficiency $\left(\mathrm{kg} \cdot \mathrm{cm}^{-2}\right.$ TCA $)$} \\
\cline { 2 - 6 } Rootstock & 1990 & 1992 & 1994 & 1995 & 1996 \\
\hline Sg. Siput & 0.210 & 0.163 & 0.213 & 0.100 & 0.101 \\
False Julie & 0.101 & 0.180 & 0.280 & 0.043 & 0.081 \\
Pineapple & 0.154 & 0.154 & 0.273 & 0.069 & 0.075 \\
Kensington Pride & 0.168 & 0.185 & 0.267 & 0.066 & 0.073 \\
Teluk Anson & 0.146 & 0.157 & 0.198 & 0.040 & 0.040 \\
Strawberry & 0.132 & 0.175 & 0.229 & 0.047 & 0.092 \\
Mempelam Telur & 0.095 & 0.132 & 0.198 & 0.058 & 0.084 \\
Lemon D2 & 0.071 & 0.134 & 0.210 & 0.046 & 0.086 \\
Sabre & 0.122 & 0.124 & 0.155 & 0.072 & 0.028 \\
$P$ value & 0.106 & 0.028 & $<0.001$ & 0.130 & 0.006 \\
LSD $_{0.05}$ & NS & 0.040 & 0.057 & NS & 0.038 \\
\hline
\end{tabular}


Table 4. Harvest rate (weight of fruit picked per person per minute) of 'Kensington Pride' mango trees on nine rootstocks.

\begin{tabular}{llcc}
\hline & \multicolumn{3}{c}{$\begin{array}{c}\text { Harvest rate } \\
\text { (kg/person/min) }\end{array}$} \\
\cline { 2 - 4 } Rootstock & 1993 & 1994 & 1995 \\
\hline Sg. Siput & 1.97 & 1.94 & 2.13 \\
False Julie & 2.12 & 2.05 & 1.81 \\
Pineapple & 2.00 & 2.54 & 1.73 \\
Kensington Pride & 2.06 & 2.12 & 1.45 \\
Teluk Anson & 1.71 & 1.85 & 0.99 \\
Strawberry & 1.79 & 2.03 & 1.12 \\
Mempelam Telur & 1.57 & 1.89 & 1.24 \\
Lemon D2 & 1.74 & 2.26 & 1.53 \\
Sabre & 1.55 & 2.07 & 1.29 \\
$P$ value & 0.048 & 0.228 & 0.019 \\
LSD $_{0.05}$ & 0.407 & NS & 0.637 \\
\hline
\end{tabular}

CSA basis) and that of Avila-Reséndiz et al. (1993), may be a better basis for expressing yield efficiency in mango because they enable more meaningful comparisons between trees of different ages and sizes. Although TCA has the advantage of being a simple method of determining tree size, it may not be as reliable as CSA in describing the tree canopy surface, particularly under production systems in which trees are subject to extensive pruning.

The vigorous growth habit of many mango scion cultivars has stimulated widespread interest in obtaining dwarfing rootstocks. In our work, we have concentrated efforts on the likely commercial effects of tree size rather than tree size itself, in line with the recommendations of Cull (1991) to focus on "... canopy surface performance, rather than to chasing this mystical character called dwarfness." Harvesting is one of the most expensive operations in mango cultivation (Crane et al., 1997) and yet little work has examined rootstock effects on harvest rates. Our results suggest that harvest rates are poorly correlated with tree size (as measured by CSA and TCA), and there is no evidence that larger trees had slower harvest rates. Furthermore, the strongest correlations between harvest rates and measures of yield efficiency sugges that harvesting is fastest on those trees with the highest yield efficiency. However yield efficiency measures were not always strongly correlated with harvest rates, and therefore assessment of actual harvest times may provide a more direct and accurate measure of this important crop production cost.

Erratic yield patterns are a major constraint to commercial mango production with annual yields fluctuating by as much as $150 \%$ (Schaf-
Table 5. Correlation $(r)$ between harvest rates and eight different measurements of tree size (canopy silhouette area, CSA; and trunk cross-sectional area, TCA) for 'Kensington Pride' mango on nine rootstocks. Correlations based on individual tree data, $\mathrm{N}=54$.

\begin{tabular}{llrrr}
\hline & & \multicolumn{3}{c}{ Harvest rate } \\
\cline { 3 - 5 } & & 1993 & 1994 & 1995 \\
\hline CSA & 1990 & 0.437 & -0.142 & 0.517 \\
& 1993 & 0.304 & -0.144 & 0.440 \\
& 1996 & 0.058 & -0.084 & 0.340 \\
TCA & 1990 & 0.034 & 0.019 & 0.181 \\
& 1992 & 0.038 & -0.068 & 0.278 \\
& 1994 & 0.088 & -0.075 & 0.309 \\
& 1995 & 0.172 & -0.060 & 0.335 \\
& 1996 & 0.132 & -0.048 & 0.316 \\
\hline
\end{tabular}

fer et al., 1994). Consequently it is important to consider rootstock influences in individual seasons as well as cumulatively across a number of seasons. In our experiment, yields in both 1995 and 1996 were very much lower than those of 1994. However the magnitude of these variations in yield were not consistent between different rootstock treatments. For example 'False Julie' which had produced the highest yield ( $221 \mathrm{~kg} /$ tree $)$ in 1994 dropped to only one quarter of this $(51 \mathrm{~kg} /$ tree $)$ in 1995 , recovering to $87 \mathrm{~kg} /$ tree in 1996 . Conversely, 'Sg. Siput' which had produced a similar yield to 'False Julie' in 1994 (217 kg/tree) dropped to half of this ( $108 \mathrm{~kg} /$ tree) in 1995 and produced $121 \mathrm{~kg} /$ tree in 1996. Thus although 'Sg. Siput' was subject to the same pattern of yield variation, the magnitude of these swings was not as severe, and it was able to produce a good crop in a low-yielding season. These results also illustrate the potential pitfalls with short term assessment of rootstock experiments.

'Sabre' was the only treatment in the experiment that had been previously examined as a rootstock. In our work it has performed very poorly, producing the lowest yields, low yield efficiencies and often slow harvest rates. This is in contrast to the finding of Oppenheimer (1968) who considered it the superior rootstock for non-problematic soils dangers of excessive extrapolation of rootstock results, and underline the need for localised evaluation of rootstock performance with the appropriate scions and under the prevailing edaphic/climatic conditions.

Other rootstocks included in this work were simply a random selection of polyembryonic scion cultivars available from the arboretum in Israel. Such inconsistencies illustrate the

at the commencement of the experiment. With the exception of 'Sabre' and 'Kensington Pride', they had not been considered as rootstocks prior to the experiment. The fact that such large differences were found in the performance of this small random selection of genotypes points to encouraging prospects for even greater improvements through rootstock selection and breeding.

Considerable genetic diversity exists within polyembryonic cultivars and there are additional prospects for exploiting related species (Bompard and Schnell, 1997) or utilizing monoembryonic types through vegetative propagation (Lavi et al., 1997). Adaptation to unfavorable edaphic/climatic conditions has been the desired outcome of much of the existing breeding and evaluation work with mango rootstocks (Hoult et al., 1997; Lavi et al., 1997; Rossetto et al., 1997; Schmutz, 2000). In such cases, the selection criteria simply involved identifying genotypes best able to withstand the unfavourable conditions at a given site. Purposeful rootstock breeding for improved yield efficiency in mango may be just as effective and help to overcome a major limitation with this crop. The simple genetic control of the polyembryonic trait (Aron et al., 1998) and the resulting ease with which new polyembryonic genotypes can be generated in a breeding program (Whiley and Saranah, 1995) favor the development of improved rootstocks that could be readily incorporated into existing commercial production systems.

The exact identity and origin of 'Sg. Siput' is somewhat unclear because the original seed source tree for the rootstock experiment was destroyed before data collection commenced. However, trees grafted from this original tree have displayed characteristics consistent with the description for 'Sg. Siput' (syn. 'MA159', 'Bahagia') provided in Salma and Masrom (1992). In our experiment, 'Sg. Siput' has emerged as the superior rootstock for 'Kensington Pride'. It consistently produced the highest, or amongst the highest, yields in each of the nine seasons examined, and on a cumulative basis out-yielded the next best treatment by $41 \%$ and the worst treatment by $141 \%$. The capacity of this rootstock to outperform others, beginning at a young age, and to provide good yields in low-yielding seasons has important economic implications. Furthermore, yield efficiency (on a CSA basis) was superior in all three of the seasons in which it was measured, and harvest rates on this rootstock were high.

\section{Literature Cited}

of yield efficiency (calculated on a canopy silhouette area basis-CSA, and on a trunk cross-sectional area basis-TCA) for 'Kensington Pride' mango on nine rootstocks. Correlations based on individual tree data, $\mathrm{N}=54$.

\begin{tabular}{lrrrr}
\hline & & \multicolumn{3}{c}{ Harvest rate } \\
\cline { 3 - 5 } & & 1993 & \multicolumn{1}{c}{1994} & 1995 \\
\hline Yield efficiency (CSA basis) & 1990 & 0.262 & -0.024 & 0.334 \\
& 1993 & 0.427 & 0.108 & 0.493 \\
Yield efficiency (TCA basis) & 1996 & 0.008 & -0.030 & 0.153 \\
& 1990 & 0.372 & -0.047 & 0.348 \\
& 1992 & 0.317 & 0.012 & 0.137 \\
& 1994 & 0.204 & 0.328 & -0.082 \\
& 1995 & 0.567 & -0.041 & 0.764 \\
& 1996 & -0.031 & -0.027 & 0.090 \\
\hline
\end{tabular}

Aron, Y., H. Czosnek, S. Gazit, and C. Degani. 1998. Polyembryony in mango (Mangifera indica $\mathrm{L}$.) is controlled by a single dominant gene. HortScience 33:1241-1242.

Avila-Reséndiz, C., R. Mosqueda-Vázquez, E. Pérez-Garcia, and L. Matheis-Toledano. 1993. Production efficiency of compact 'Manila' stock combinations. Acta Hort. 341:281-287.

Avilán, L., F. Leal, M. Rodriguez, J. Ruiz, and C. Marin. 1997. Mango rootstocks and their influence on fruit shape and size. Acta Hort. 455:479-488. mango grafted onto different interstock-root- 


\section{Breeding, Cultivars, Rootstocks, \& Germplasm Resources}

Bompard, J.M. and R.J. Schnell. 1997. Taxonomy and systematics, p. 21-47. In: R.E. Litz (ed.) The mango: Botany, production and uses. CAB Intl., Wallingford.

Chapman, K.R. 2000. Mango - Special challenges in Asia and Oceania. Acta Hort. 509:95-105.

Crane, J.H., I.S.E. Bally, R.V. Mosqueda-Vázquez, and E. Tomer. 1997. Crop production, p. 203256. In: R.E. Litz (ed.). The mango: Botany, production and uses. CAB Intl.,Wallingford.

Cull, B.W. 1991. Mango crop management. Acta Hort. 291:154-173.

FAO. 2001. FAOSTAT Agriculture data. [http: //apps.fao.org/cgi-bin/nph-db.pl?subset=agri culture] (10 Nov. 2001).

Galán Saúco, V. 1997a. Horticultural practices in mango. Acta Hort. 455:391-400.

Galán Saúco, V. 1997b. Mango world production (outside Israel, Egypt and India). Acta Hort. 455:391-400.

Gowder, R.B. and I. Irulappan. 1971. Performance of Neelum variety of mango (Mangifera indica L.) on polyembryonic rootstocks as compared to that on monoembryonic rootstock. Madras Agr. J. 58:183-189.

Hoult, M.D., M.M. Donnelly, and M.W. Smith. 1997. Salt exclusion varies amongst polyembryonic mango cultivar seedlings. Acta Hort. 455:455-458.

Kurian, R.M., V.V.P. Reddy, and Y.T.N. Reddy. 1996. Growth, yield, fruit quality and leaf nutrient status of thirteen year old 'Alphonso' mango trees on eight rootstocks. J. Hort. Sci. 71:181-186.

Lavi, U., D. Kaufman, D. Sharon, A. Adato, E. Tomer, S. Gazit, and J. Hillel. 1997. Mango breeding and genetics-Review. Acta Hort. 455:268-276.

Negi, S.S. 2000. Mango production in India. Acta Hort. 509:69-78.

Oppenheimer, Ch. 1968. A second stock-scion trial with mango in Israel. Expl. Agr. 4:209-218.

Perez, A., M.A. Cedeno, S.I. Reyes, and J. Lopez. 1988. Dwarfing effect of interstems on growth and yield components of mango. J. Agr. Univ. P.R. 72:501-508.

Ram, S. 1997. Propagation, p. 363-400. In: R.E. Litz (ed.) The mango: Botany, production and uses. CAB Intl., Wallingford.

Richards, N.K. 1992. Cashew tree nutrition related to biomass accumulation, nutrient composition and nutient [sic] cycling in sandy red earths of Northern Territory, Australia. Scientia Hort. 52:125-142.

Rossetto, C.J., I.J.A. Ribeiro, P.B. Gallo, N.B. Soares, J.C. Sabino, A.L.M. Martins, N. Bortoletto, and E.M. Paulo. 1997. Mango breeding for resistance to diseases and pests. Acta Hort. 455:299-304.

Salma, I. and H. Masrom. 1992. A systematic description of mango clones in Peninsular Malaysia. MARDI Rpt. 151. MARDI, Kuala Lumpur, Malaysia.

Samaddar, H.N. and U. Chakrabarti. 1988. Effects of different rootstocks on Himsagar and Langra. Acta Hort. 231:220-224.

Schaffer, B., A.W. Whiley, and J.H. Crane. 1994. Mango, p.165-197. In: B. Schaffer and P.C. Anderson (eds.). Handbook of environmental physiology of fruit crops Volume II: Subtropical and tropical crops. CRC Press, Boca Raton, Fla.

Schmutz, U. 2000. Effect of salt stress $(\mathrm{NaCl})$ on whole plant $\mathrm{CO}_{2}$-gas exchange in mango. Acta Hort. 509:269-276.

Scholefield, P.B., I. Baker, and D.M. Alexander 1986. Flowering, maturity time, production and fruit characteristics of mango cultivars in the Northern Territory, p. 173-185. In: Standing committee on agriculture. First Australian mango research workshop. CSIRO Press, Melbourne, Australia.

Smith, M.W., M.D. Hoult, J.D. Bright, S. McAlister, and G. Foord. 1997. Rootstock research: Opportunities for the Australian mango industry. Acta Hort. 455:383-390.

Whiley, A.W. and J.B. Saranah. 1995. Breeding mangoes in sub-tropical Australia. QDPI Conference and Workshop Series QC95006, Brisbane, Australia. p. 55-59.

Wolstenholme, B.N. and A.W. Whiley. 1995. Ecophysiology of the mango tree as a basis for pre-harvest management. QDPIConference and Workshop Series QC95006, Brisbane, Australia. p. 5-19. 